УДК 612.79:636.2

(C) 2013

Кириловський С. М., асистент

Львівський національний університет ветеринарної медицини та біотехнологій ім. С. 3. Гжицького

\title{
ГІСТОЛОГІЧНА ХАРАКТЕРИСТИКА МІЖКЛІТИННИХ КОМПОНЕНТІВ СОСОЧКОВОГО ШАРУ ДЕРМИ ШКІРИ ТЕЛИЦЬ РІЗНИХ ПОРІД У ПОСТНАТАЛЬНОМУ ОНТОГЕНЕЗІ
}

\section{Рецензент - доктор ветеринарних наук В. I. Завірюха}

\begin{abstract}
Сосочковий шар дерми шкіри телиць має складну неоднорідну організацію міжклітинної речовини сполучної тканини й топографічно розділяється за морфологічними ознаками колагенових, еластичних, ретикулярних волокон і основної речовини на декілька рівнів. Ріст папілярного шару дерми шкіри телиць супроводжусться внутрішніми структурними перетвореннями папілярного шару дерми. У ранньому віці чітко проявляються відмінності в архітектоніці колагенової сітки на субепідермальному рівні папілярного шару дерми у різних порід телииь.
\end{abstract}

Ключові слова: дерма, сосочковий шар, колагенові, еластичні, ретикулярні волокна, кислі мукополісахариди основної речовини.

Постановка проблеми. Шкірний покрив великої рогатої худоби відіграє важливу захисну та адаптивну роль в організмі. Функціональна діяльність органа тісно пов'язана зі структурною організацією. Так, ефективність тепловіддачі залежить від морфологічних ознак волосся та потових залоз, а захисні властивості забезпечуються організацією шарів шкіри - епідермісу, дерми й підшкірної основи $[1,4]$. Формування шкіри відбувається у ранньому онтогенезі, генетично детерміноване і за ступенем розвитку відрізняється у різних порід худоби [2].

За даними досліджень із реконструкції шкіри in vitro та експериментів на лабораторних тваринах, розкриваються складні взаємодії в процесі морфогенезу між клітинами, клітинами і позаклітинним матриксом, епітеліальною та сполучною тканинами [5]. На основі знань закономірності розвитку гістоструктури шкіри та змін, які вносять фактори середовища, поряд із питаннями раннього прогнозування властивостей покриву, попередження або усунення вад, доцільно розглядати питання направленого впливу на прояв сприятливих морфологічних ознак шкіри у процесі вдосконалення перспективних для розведення українських молочних порід худоби.

Аналіз основних досліджень і публікацій, у яких започатковано розв'язання проблеми.
Дерму традиційно поділяють на сосочковий та сітчастий шари, кожен $з$ яких має свою унікальну структуру та функції. Ріст дерми відбувається за рахунок синтезу фібробластами міжклітинної речовини, але формування сосочкового шару (на відміну від сітчастого) здійснюється у тісній взаємодії зі структурами епітеліального походження - епідермісом, волосяними фолікулами та залозами шкіри, що і визначає особливості його архітектоніки [3]. Опорні компоненти міжклітинної речовини - колагенові волокна, мікрофібрили еластичних волокон та мукополісахариди в'язкого гелю основної речовини зв'язують фактори росту і локально діють на процеси морфогенезу у сполучній тканині шкіри [7].

За даними, які наводяться для лабораторних тварин і людини, в процесі росту шкіри змінюється співвідношення клітин та міжклітинної речовини, міжклітинних компонентів дерми, морфологічні ознаки, фізичні й хімічні властивості волокон $[6,8]$. Проте у доступній нам літературі фактично відсутні описові гістологічні характеристики, які б відображали ці зміни у дермі в постнатальному розвитку у великої рогатої худоби. У власних попередніх роботах наводилися морфометричні показники динаміки росту шкіри та похідних - волосся, потових і сальних залоз - у телиць чорно-рябої, симентальської, української чорно- та червонорябої молочних порід після народження [1]. Гістологічні та гістохімічні дані доповнюють картину морфогенезу шкірного покриву.

Метою роботи було дати гістологічну характеристику міжклітинних елементів сосочкового шару дерми шкіри у різних порід телиць у процесі постнатального розвитку.

Завдання досліджень: виявити відмінності в архітектоніці колагенової сітки на субепідермальному рівні папілярного шару дерми у різних порід телиць; дослідити ріст папілярного шару дерми шкіри телиць.

Матеріали і методи досліджень. У дослідному господарстві «Грусятичі» Жидачевського ра- 
йону Львівської області проводили дослідження на телицях чотирьох різних порід, сформованих у групи по 15 голів у кожній (аналогів за віком і походженням) за схемою:

I група (контрольна) - чорно-ряба порода,

II група (дослідна) - українська чорно-ряба молочна порода,

III група (контрольна) - симентальська порода,

IV група (дослідна) - українська червоно-ряба молочна порода.

Телиці всіх 4-х груп перебували в однакових умовах годівлі й утримання.

Препарати 3 біопсійного матеріалу, взятого 3 середньої третини шиї від телиць 3-, 6-, 9-, 12-, 15- і 18-місячного віку, виготовлялися за загальними гістологічними методиками.

Фарбували гематоксилін-еозином; за ВанГізоном; резорцин-фуксином Вейгерта; альциановим синім і тіоніном; по Папу; по Браше, на ДНК, РНК; за Пірсом, на SS-групи. Досліджувані показники вимірювали мікрометром АМ-9-2.

Результати досліджень. Сосочковий шар шкіри телиць має неоднорідну будову. За ознаками товщини, напрямом і щільністю розміщення колагенових, еластичних та ретикулярних волокон, співвідношенням основної аморфної речовини й волокон у сосочковому шарі простежуються різні рівні організації: субепідермальний - від базальної мембрани епідермісу до основи сальних залоз, проміжний - між основою сальних та верхівкою потових залоз і перехід- ний, який поступово переходить у ретикулярний шар.

Характерні відмінності визначаються структурою колагенової сітки волокон, яка є домінуючим компонентом міжклітинної речовини дерми.

На субепідермальному рівні тонкі колагенові волокна розміщуються пухко і проходять у різних напрямках, вони здійснюють зв'язок із базальною мембраною епідермісу, а в проміжному й перехідному ідуть щільно, паралельно поверхні шкіри, але у перпендикулярних площинах, і в проміжному на відміну від перехідного, вони тісно пов'язані 3 волосяними фолікулами (рис. 1).

Додатковими орієнтирами у визначенні рівнів можуть служити інші елементи сполучної тканини. Густу сітку формують еластичні волокна в сосочковому шарі на проміжному рівні. Тут вони, як і колагенові волокна, пов'язані зі сполучнотканинними сумками волосяних фолікулів. Під епідермісом волокна займають висхідне положення, занурені якірними фібрилами в базальну мембрану, сітка волокон має обрідний вигляд, вона краще розвинена тільки в української червоно-рябої, що вирізняє іiі з-поміж інших порід телиць (рис. 2).

Ретикулярні волокна входять до складу базальної мембрани, оточують придатки шкіри, постійно виявляються на переході між грубою колагеновою сіткою та судинами. Вони відносно рівномірно розміщуються у верхній ділянці сосочкового шару (рис. 3).
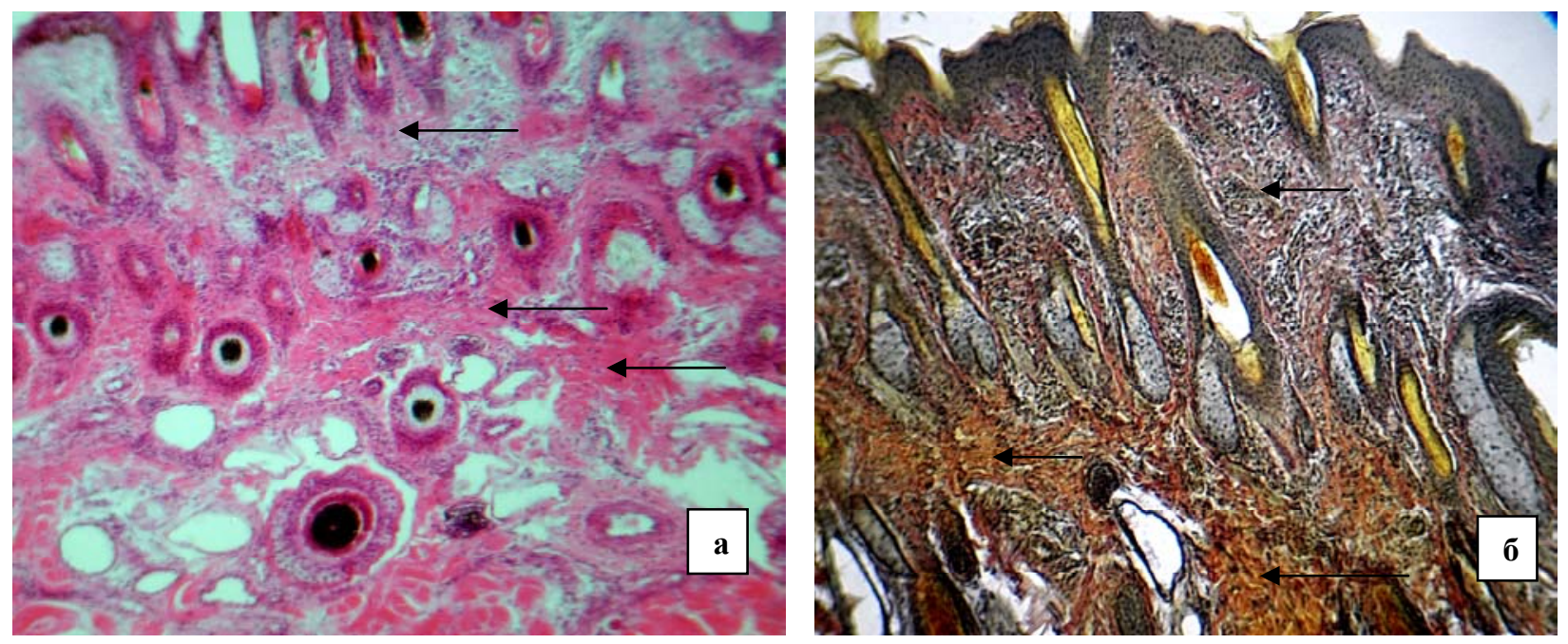

Рис. 1. Колагенові волокна у папілярному шарі шкіри телиць (х80). Гематоксилін і еозин (а), фарб. за Ван-Гізоном (б) 

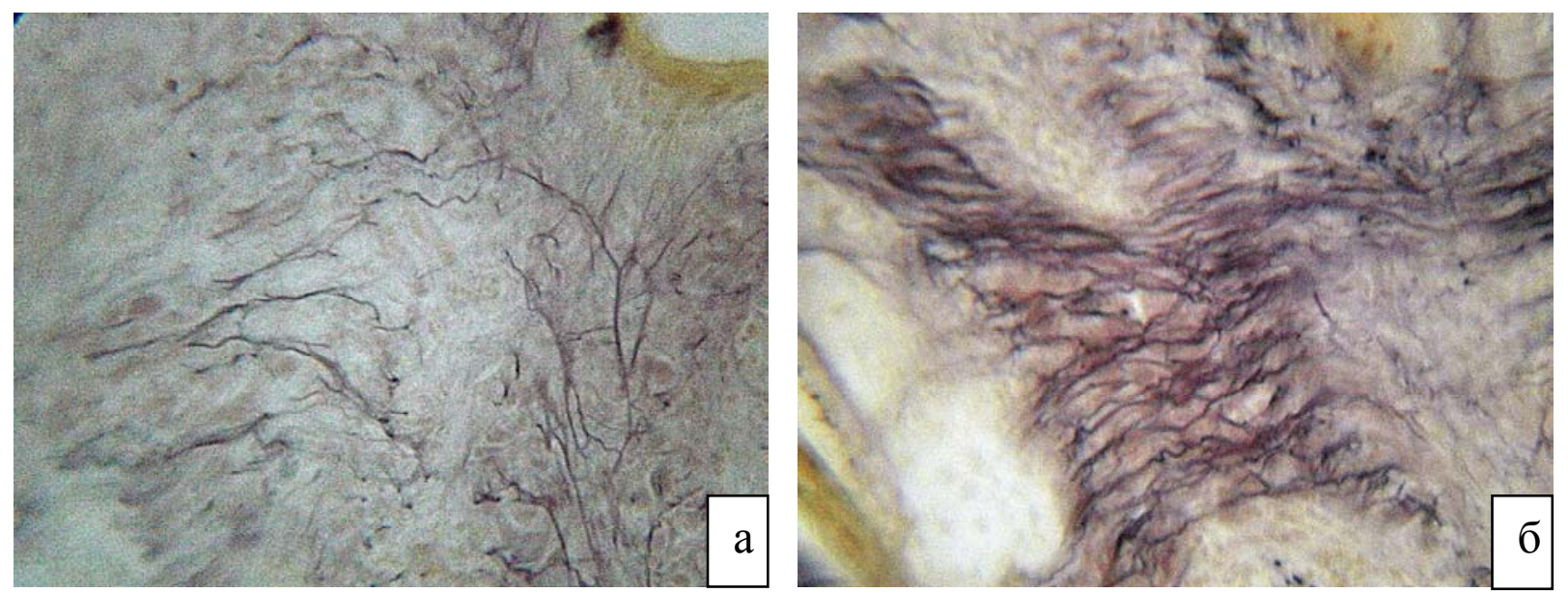

Рис. 2. Еластичні волокна в папілярному шарі дерми під епідермісом (а) та на рівні сальних і потових залоз (б) (х400). Резорцин-фуксин за Вейгертом.

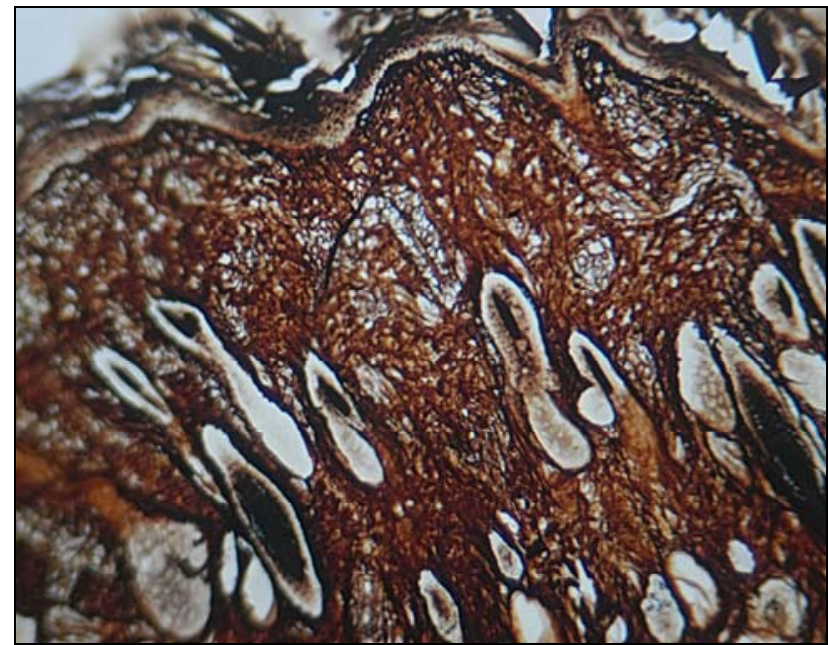

Рис. 3. Ретикулярні волокна в папілярному шарі дерми шкіри (х 80). Імпрегнація сріблом за Футом.

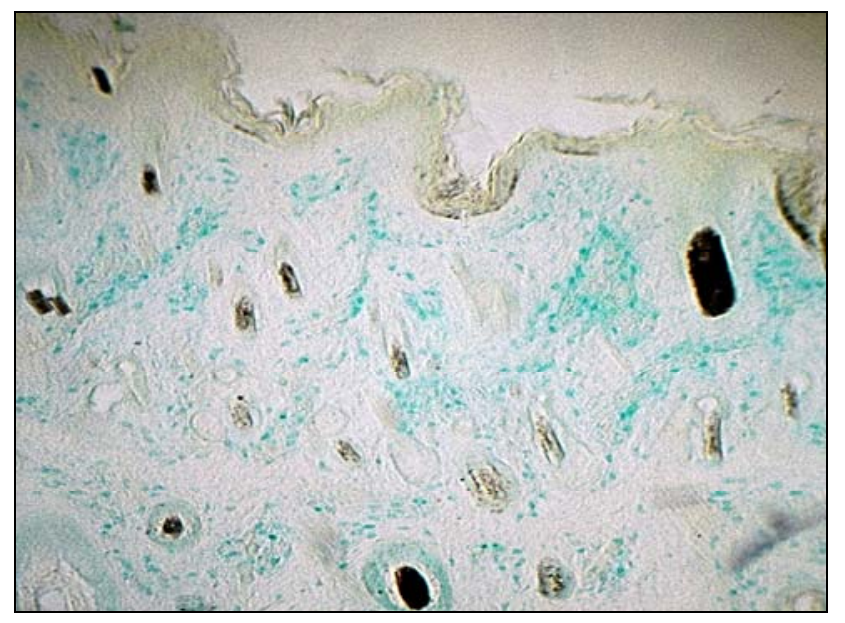

Рис. 4. Кислі мукополісахариди в папілярному шарі дерми шкіри (х80). Фарб. альциановим синім за Стідманом.
Кислі мукополісариди аморфної речовини в достатній кількості регулярно виявляються серед волокон на субепідермальному та проміжному рівнях (рис. 4).

Процеси росту та диференціації сосочкового шару, згідно з гістологічними дослідженнями, у порід телиць відбуваються за однаковим типом. На морфологію папілярного шару значний вплив спричиняє суттєвий приріст товщини між 3-м та 6-м місяцями постнатального онтогенезу [1], що супроводжується змінами у волокнистому компоненті проміжної речовини у 6-місячних й, частково, 9-місячних телиць. Колагенові волокна порівняно 3 попереднім періодом у 3-місячному віці втрачають властивий їм компактний вид укладки - між ними починають виявлятись інші елементи сполучної тканини: імпрегнуються не окремі волокна, а розвинена тонка ретикулярна сітка, зростає кількість еластичних волокон, які розгалужуються у середній ділянці папілярного шару. Із віком надзвичайно інтенсивно розвивається колагенова сітка: збільшується кількість, діаметр і щільність волокон. Вони стають переважаючим компонентом міжклітинної речовини. Затиснені еластичні волокна між компактно розміщеними колагеновими мають фрагментарний малюнок, а тонкі ретикулярні волокна концентруються довкола судин і відтиснені до придатків шкіри. Логічно очікувати, що зміни аморфної субстанції підпорядковані тим самим закономірностям, що й інші міжклітинні елементи сполучної тканини. Навпаки, рівень концентрації кислих мукополісахаридів підвищується в шкірі зі щільною текстурою волокон, особливо в пізньому онтогенезі у порід телиць, починаючи 3 12-місячного віку. Тільки у сименталів відмічається надзвичайно висока реакція на початку досліду в 3-місячних телят. 
У цілому у контрольних груп телиць, на відміну від дослідних, більш активна реакція на кислі мукополісахариди.

У ранньому віці чітко проявляються відмінності в архітектоніці колагенової сітки на субепідермальному рівні у різних порід телиць: у шкірі дослідних груп (української чорно- та червоно-рябої молочної порід) сформована комбінацією товстих i тонких, а в контрольних груп (чорно-рябої та симентальської порід) - відносно товстими волокнами.

Типовою ознакою сосочкового шару дерми в української чорно-рябої породи $\epsilon$ нещільна текстура сітки колагенових волокон, порівняно з іншими породами телиць, незалежно від віку.

\section{БІБЛІОГРАФІЯ}

1. Венгрин А. В. Вікові зміни структурної організації шкіри та загальної резистентності організму у великої рогатої худоби різних порід / Венгрин А. В., Кириловський С. М. // Науково-техн. бюл. Інституту біол. твар., ДНДКІ ветпрепаратів та корм. добавок. - Львів, 2009. - В. 10, № 1-2. C. 382-392.

2. Кацы Г. Д. Методические рекомендации по исследованию кожи млекопитающих. - Херсон : ТИНП. - 1987. -25 с.

3. Техвер Ю. Т. Гистология кожного покрова домашних животных / Ю. Т. Техвер - Тарту : Издво Эстонской сельхоз. акад. - 1971. - 112 с.

4. Carter H. B. The hair follicle and apocrine gland population of cattle. / Carter H. B., Dolling D. F. // Aust. J. Agric. Res. - 1954. - 5. - P. 745.

\section{Висновки:}

1. Встановлено різні топографічні рівні організації сосочкового шару дерми шкіри телиць у залежності від морфологічних характеристик та розподілу колагенових, еластичних, ретикулярних волокон і кислих мукополісахаридів основної речовини.

2. Ріст шкіри телиць у постнатальному онтогенезі супроводжується видимими структурними перетвореннями міжклітинних компонентів сосочкового шару дерми.

3. Морфологічні особливості будови сітки колагенових волокон, поряд 3 іншими ознаками дерми, дають змогу ідентифікувати породну належність шкіри телиць.

5. Dubertret L. Reconstruction of the human skin equivalent in vitro: a new tool for skin biology. I Dubertret L. // Skin Pharmacol. - 1990. - 3, № 2. P. 144-148.

6. Röck $K$. Role of the extracellular matrix in extrinsic skin aging. / Röck K., Fischer J.W. // Hautarzt. 2011. - 62(8). - P. 591-597.

7. Ushiki T. Collagen fibers, reticular fibers and elastic fibers. A comprehensive understanding from a morphological viewpoint. // Arch Histol Cytol. 2002. - 65(2). - P. 109-126.

8. Vogel M. G. Influence of maturation and ageing on mechanical and biochemical properties of connective tissue in rats // Mech. Ageing and Dev. 1980. - Vol. 14, № 3-4. - P. 283-292. 